\title{
$\mathrm{XX}$ a. Klaipėdos krašto gyventojų klaipėdiškių kultūrinio ir tautinio tapatumo išraiškos epitafijose
}

\author{
SILVA POCYTE் \\ Klaipedos universiteto Baltijos regiono istorijos ir archeologijos institutas, Herkaus Manto g. 84, LT-92294 Klaipèda \\ El. paštas: silva.pocyte@gmail.com
}

\begin{abstract}
Straipsnyje (1), panaudojant užfiksuoto konfesinio paveldo medžiagą, pateikiami Klaipèdos krašto kultūrinio ir tautinio gyventojų tapatumo aspektai. Remiantis senosiose krašto evangelikų-liuteronų kapinèse išlikusių epitafijų įrašais, rekonstruojama laidojimo tradicijoje atsispindejjusi kultūrinè ir kalbinè vietos gyventojų - lietuvininkų ir vokiečių - aplinka nuo XIX a. antrosios pusès; pateikiami dvikalbiai tarpukario laikotarpio epitafijų pavyzdžiai; analizuojami Klaipedos krašte likusių vietinių gyventojų - klaipèdiškių - tautinio tapatumo raiška pasikeitusiomis politinèmis ir kultūrinemis sąlygomis po $1945 \mathrm{~m}$.
\end{abstract}

Raktažodžiai: Klaipėdos kraštas, konfesinis paveldas, senosios kapinès, klaipėdiškiai

Lenkų istorikas Robertas Traba, tiriantis kultūrinius kontaktus ir pokyčius lenkų ir vokiečių pasienio regione XIX-XX a., pažymi, jog Rytų Prūsija yra kraštas, „draugystès ryšiais sujungiančios multikultūros įrodymas, tačiau sykiu ir „kitų“ kultūrų bei nacionalinių mažumų laimejjimų griovimo pavyzdys" $[49,26]$. Šis teiginys iliustratyviai atspindi ir Rytų Prūsijos šiaurinès dalies - Klaipèdos krašto - istorijos daugiakultūrinę sampratą, kurios refleksijos yra svarbios nagrinejjant krašto gyventojų kultūrines ir tautines raiškas XX a. bei suvokiant regiono kitoniškumą bendrame Lietuvos istorijos kontekste.

$\mathrm{XX}$ a. Klaipėdos krašto istorija, jos lūžio momentai, susiję su pasaulinių karų padiktuotais politiniais virsmais, pastaruoju metu sulaukia progresyviai didejančio istorikų ir kitų sričių mokslininkų dèmesio. Visgi tenka pažymėti, kad labiau ištyrinèta Klaipėdos krašto istorija iki 1939 m., daugiau dėmesio sutelkiant ì politinès, kultūrinès, ekonominès raidos aspektus krašte autonomijos laikotarpiu 1923-1939 metais. Reikia pripažinti, kad 1998 m. Vokietijos mokslininko Joachimo Tauberio išsakyta mintis, jog Lietuvai atgavus Nepriklausomybę abiejų šalių mokslininkų tyrimai daugiausia apėmè didžiąją tuometinę Berlyno ir Kauno politiką bei atskirus politinius ịvykius - nacionalsocialistinès Vokietijos ultimatumą Lietuvai ir Klaipėdos krašto atidavimą 1939 m. kovo mėnesį, taip pat „1923 m. sausio ménesio ịvykiai, susiję su lietuvių ižygiavimu“ i Klaipèdos kraštą [47, 85], pakankamai aktuali ir šiandieninei istoriografijos situacijai. $2012 \mathrm{~m}$. Vytauto Žalio išleistame Lietuvos

(1) Straipsnis parengtas $2013 \mathrm{~m}$. vykdant Lietuvos mokslo tarybos finansuojamos mokslo programos „Valstybė ir tauta: paveldas ir tapatumas“ projektą „Klaipėdos krašto etnokonfesinio paveldo tyrimai, sukuriant geografinę informacinę sistemą“ (2012-2014 m., Nr. VAT-12018). 
diplomatijos istorijos antrame tome, aptariant Vokietijos ir Lietuvos santykius nuo $1929 \mathrm{~m}$. vasaros iki 1931 m. pabaigos, išskirtinis dėmesys skiriamas Klaipėdos krašto bylai [62; 63], ivairialypiai krašto politinès istorijos siužetai atskleidžiami ir kitų istorikų darbuose [19; 20]. Kalbant apie 1939-1945 m. laikotarpi Klaipėdos krašte, pažymėtina, jog greičiausiai dèl pirminių šaltinių stokos šis periodas nèra pakankamai išanalizuotas, nors per pastaruosius kelerius metus pasirodè tyrimai apie Klaipėdos krašto gyventojų padèti po 1939 m. [2], pateikti Vokietijos militarinès istorijos Klaipėdoje siužetai [42]. Negalima teigti, kad kultūriniai krašto istorijos aspektai mokslininkų darbuose lieka paraštėse, tačiau juose daugiausia pateikiami tam tikri mikrolygmens ar vienasmeniai veiklos aspektai [21; 45], o nuoseklios kultūros istorijos sintezès stokojama. Svarbi cezūra, žyminti radikalius tiek Klaipėdos krašto ir miesto, tiek visos Rytų Prūsijos politinius, socialinius, demografinius, tautinius pokyčius regione, yra 1944-1945 m. riba, kai baigiantis Antrajam pasauliniam karui pasikeitė ir krašto politinės priklausomybės statusas, ir krašto gyventojų sudètis [1]. Laikotarpis po $1945 \mathrm{~m}$. suponuoja daug aktualių tyrinėtinų temų: sovietinių / politinių struktūrų kūrimasis ir visos krašto administracinès sistemos integravimas ị sovietinę sistemą (pvz., apie Šilutės apskrities kūrimąsi žr. [8]), ekonomikos sovietizacija, senųjų kultūrinių tradicijų devalvacija ir naujosios ideologijos panauda ịsisavinant buvusios Rytų Prūsijos erdves [9].

Klaipedos krašto istorijos po 1945 m. kontekste neabejotinai aktuali tema yra ištuštèjusio krašto apgyvendinimas ir likusių vietinių gyventojų - lietuvininkų ir vokiečiu (apibendrintai vadintinų klaipédiškiais) - padètis pasikeitusiomis politinėmis sąlygomis, jų tautinès ir kultūrinès saviraiškos, naujosios aplinkos (ne)prièmimo problematika, santykiai su naujakuriais. Socialinius-demografinius klausimus viso krašto lygmeniu yra nagrinejjusi Nastazija Kairiūkštytė $[14 ; 15]$; doc. A. Arbušauskaitė daugiau akcentavo demografinius pokyčius Kuršių nerijoje [4]. Bendrus Klaipėdos krašto raidos po 1945 m. aspektus aptarè Ruth Kibelka [17], svarbiausius klaipèdiškių padėties bruožus siekė atskleisti Arthuras Hermannas [11]. Visgi kalbant apie Klaipedos kraštą po Antrojo pasaulinio karo tenka konstatuoti, jog vietinių krašto gyventojų padètis šiuo laikotarpiu dar nèra pakankamai išanalizuota tema, nors ir pateikiamos metodologinès pokario istorijos tyrimų prieigos [32], publikuojami ano meto archyviniai šaltiniai [3] ir vietinių gyventojų prisiminimai $[28 ; 48 ; 23]$.

Po masinès gyventojų evakuacijos baigiantis Antrajam pasauliniam karui ir pirmujų pokario metų repatriacijos $1950 \mathrm{~m}$. Klaipedos krašte buvo suskaičiuota 15-20 000 klaipẻdiškių (lietuvininkų ir vokiečių) [25, 363], iš kurių apie 8000 sudarè repatriantai [15, 45]. Kaip mini N. Kairiūkštytė, dauguma repatriantų vyko ị kaimą, „tačiau ne visiems valstiečiams, net grị̌usiems 1945 m., pasisekè apsigyventi savo ūkiuose, o grižusieji vẻliau turèjo dar mažiau galimybių patekti ị savo namus, nes jų ūkiai beveik visi buvo išdalinti naujakuriams, organizacijoms" $[15,44]$. Savų namų gimtinejje praradimas, pasikeitusi politinè, socialinè, ekonominè situacija, baimè būti išvežtam į Sibirą, skaudūs karo pabaigoje patirti išgyvenimai ir artimųjų netektys, išblaškytos šeimos ir bandymai surasti likusius gyvuosius (2) - klaipėdiškiams reikejo daug dvasinių pastangų, kad prisitaikytų prie naujų pokarinio Klaipèdos krašto gyvenimo sąlygų.

(2) Karo pabaigoje išblaškytų šeimų istorijas liudija po Antrojo pasaulio karo $1950 \mathrm{~m}$. Vokietijoje atnaujinto iki 1945 m. pradžios Klaipėdoje leisto laikraščio Memeler Dampfboot (1948-1949 m. - Memeler Rundbrief) puslapiuose spausdinta „Familien-Chronik“ („Šeimų kronikos“). Čia daugiausia būdavo skelbiamos paieškos artimųjų, kurie dingo arba pasimete evakuacijos metu ar po jos. 
Šio straipsnio tikslas - atskleisti kultūrinès ir tautinès klaipėdiškių raiškos fragmentus $\mathrm{XX}$ a. atskirais laikotarpiais remiantis Klaipėdos krašto senosiose kapinèse išlikusiomis epitafijomis.

Tautinès klaipėdiškių raiškos analizavimas pasinaudojant iki šiol ị istoriografiją tik fragmentiškai ịtraukta epitafijose užfiksuota informacija yra svarbus Klaipėdos krašto, kaip paribio regiono, daugiakultūrès ir daugiatautès sanklodos atskleidimas, kai epitafijoje užkoduoti kalbiniai ženklai gali būti traktuojami kaip tam tikra mes - bendruomene (WirGemeinschaft) [31,9] definicijos išraiška, emociškai instrumentalizavusi tautinių grupių saviidentifikaciją.

Straipsnio uždaviniai: išanalizuoti klaipediškių kultūrinès ir tautinès raiškos aspektus $\mathrm{XX}$ a. ir atskleisti krašto gyventojų dvikalbiškumo tradiciją; nagrinèti klaipėdiškių situaciją po 1945 m. palyginus vienos evangelikų liuteronų parapijos bažnytinius dokumentus ir konfesinio paveldo duomenis.

Tyrimo chronologiniai rèmai apima laikotarpị iki 1960 m., nes klaipėdiškių grupès savastyje svarbus lūžis ịvyksta XX a. 6-ojo dešimtmečio pabaigoje, kai, remiantis $1958 \mathrm{~m}$. balandžio 8 d. pasirašyta Vokietijos Federacinės Respublikos ir Sovietų Sąjungos sutartimi, iš Klaipėdos krašto ị Vokietiją 1956-1969 m. (intensyviausias laikotarpis 1958-1960 m.) išvažiavo 8232 klaipediškiai $[38,12]$. Šis ribinis Klaipèdos krašto istorijos atskaitos taškas akivaizdžiai ištirpdè kilminių krašto gyventojų būtị savoje tèviškèje. Bendruomene „istorijos paraštëje“ neturèjo galimybių kalbėti apie savo praeitị, nes ideologinėmis grandinėmis supančiota viešoji opinija arba "grynino / lietuvino“ istoriją sau palankia linkme, arba, išskirdama tik vokiškumu paremtą Klaipėdos krašto kultūros ir istorijos supratimą, formavo svetimą ir nepriimtiną tiek viso regiono, tiek klaipédiškio Lietuvoje vaizdinį [18]. Po $1960 \mathrm{~m}$. klaipediškiai praktiškai susiniveliavo su likusiąja visuomenės dalimi ir jų savitumą galima užčiuopti bei tam tikrą savasties pulsą atpažinti iš tam tikrų religinės aplinkos, bažnytinio gyvenimo ženklų.

Šaltinių bazè. Svarbiausia šaltinių grupè, esanti tyrimo pagrindu, yra senosiose Klaipèdos krašto kapinèse išlikę antkapiniai paminklai ir juose užrašytos epitafijos, liudijančios apie palaidotus klaipediškius. Kaip pažymi Domas Kaunas, „Mažosios Lietuvos kapinès - muziejus, archyvas ir rašto saugykla po vienu stogu, kurị atstoja dangaus skliautas“ $[16,12]$, ir kuris nyksta tiek dèl žmogaus neigiamos intervencijos ị aplinką, tiek dèl gamtos poveikio. Kapinèse randami ženklai padeda atskleisti tiek krašto kasdienybės ir įsigyventą praeiti, tiek istorijos prievartos $[30,86]$ paliktus pėdsakus. Užfiksuoti šią šaltinių grupę ir įtraukti i mokslinę apyvartą leido nuo 2006 m. Klaipèdos universiteto Baltijos regiono istorijos ir archeologijos instituto vykdomos senųjų Klaipedos krašto kapinių fiksavimo ekspedicijos (3), kurių metu surinkti ịvairūs duomenys papildo Rytų Prūsijos, Prūsijos Lietuvos, Klaipėdos krašto tautinès, kultūrinès, ekonominès, socialinės istorijos siužetus, atskleidžia šeimų ir giminių, vietovių, parapijų istorijas.

Straipsnyje, aptariant klaipėdiškių situaciją po 1945 m., bus naudojamos dar dvi pirminių šaltinių grupès, kurios padès perteikti vietinių krašto gyventojų būties, kasdienybès ir kultūrinès tradicijos elementus „iš grupès vidaus“. Vienai šaltinių grupei priskirtinos nuotraukos, išlikusios ir saugomos / saugotos vietinių krašto gyventojų fotoalbumuose ar asmeninėse kolekcijose. Klaipėdos universiteto Baltijos regiono istorijos ir archeologijos

(3) 2012-2014 m. senosios kapinès fiksuojamos vykdant Lietuvos mokslo tarybos finansuojamos mokslo programos „Valstybė ir tauta: paveldas ir tapatumas“ projektą „Klaipėdos krašto etnokonfesinio paveldo tyrimai, sukuriant geografinę informacinę sistemą“ (2012-2014 m., Nr. VAT-12018). 
institutas, nuo $2005 \mathrm{~m}$. vykdantis projektą „Šeimos albumų istorijos. Klaipèdiškiai 1944-1960 metais“" (projekto vadove 2005-2006 m. - dr. Ruth Leiserowitz) (4), surinko ir skaitmeninejje duomenų bazejje sukaupė apie 1000 nuotraukų, kurios atspindi ịvairialypi klaipėdiškių gyvenimą, kasdienybės detales. Suskirsčius surinktas nuotraukas pagal temas pastebėta, jog didžiausia nuotraukų grupe yra susijusi su religine aplinka, bažnytiniu gyvenimu. Protestantizmas klaipėdiškiams buvo pagrindinis jų skirtumo nuo naujakurių kriterijus, kitokios kultūros ir mentaliteto išraiškos matmuo. Religija buvo pagrindinis jų tapatumą formavęs veiksnys ir svarbiausias ikikarinès tradicijos tęstinumo simbolis. Religijos išsaugojimą ir telkimąsi pokario bendruomenėse galima traktuoti ir kaip savotišką klaipėdiškių protestą prieš sovietų sistemos bruktą ateistinę propagandą.

Kita šaltinių grupè, problemiškiausia, tačiau neabejotinai galinti suteikti daugiausia informacijos, - veikusių bažnytiniu parapiju dokumentai. Teiginys apie pastarųjų šaltinių problemiškumą yra suponuotas neatsitiktinai, nes dauguma Klaipedos krašto bažnytinių dokumentų, rašytų iki 1944 m. pabaigos, yra dingę (5), o pokario bažnytinių dokumentų paieška ir identifikavimas dẻl išdraskytos bažnytinès struktūros yra ganètinai sudètingas. Iki Antrojo pasaulinio karo pradžios Klaipėdos krašte veikè 31 liuteronų parapija [13, 211-212], karo pabaigoje bei jam pasibaigus didžioji dalis bažnyčių buvo sugriautos (pvz., Priekulès, Smalininkų, visos trys protestantiškos bažnyčios Klaipėdoje) arba naudojamos kitoms reikmėms (pvz., Dovilų, Pagėgių, Vilkyškių, Rusnès), tik kelios bažnyčios išlaikẻ savo kaip kulto pastatų statusą ir pokariu, tarp jų ir Vanagų evangelikų liuteronų bažnyčia [37]. Šios bažnyčios kunigo Jurgio Sprogio rašyti pokario laikotarpio bažnytiniai dokumentai [59; $60 ; 53 ; 54 ; 51 ; 58 ; 46 ; 52 ; 24]$ yra unikalus šaltinis, liudijantis parapijoje gyvenusių vietinių žmonių skaičių, jų pasiskirstymą atskirais kaimais, bažnytinių sakramentų priemimą. Mūsų nagrinejjamos temos kontekste yra aktualūs mirusių parapijiečių sąrašai su nuorodomis, kada ir kokiose kapinèse jie buvo palaidoti [59, 50-100].

Tyrimo objektu pasirinkta senosiose krašto kapinėse išlikusiose epitafijose (6) užrašyta informacija, kuri padeda atskleisti gyventojų dvikalbystės tradiciją, paaiškinti krašto gyventojų tautinès ir kultūrinės raiškos ypatumus.

Iš tyrime naudojamų šaltinių pristatymo aiškejja darbo naujumas, kadangi iki šiol i istoriografinę apyvartą buvo įtraukti tik minimų šaltinių fragmentai (7). Šaltinių analizė ir jų lyginimas leis papildyti klaipèdiškių grupès tautinès ir kultūrinès raiškos ypatumų sampratą.

Tyrimo pradžioje būtina pateikti klaipediškio sąvokos apibrèžtį. Kalbant apie regiono tautinę sudètị iki 1944 m. pabaigos, išskirtinas keletą šimtmečių dominavęs (turint omenyje visą Prūsijos Lietuvos teritoriją) dviejų tautinių grupių - vokiečių ir lietuvininkų (arba Prūsijos lietuvininkų, Prūsijos lietuvių, mažlietuvių) - koegzistavimas ir bendrabūvis. Galima paminèti, jog „nuo XVI a. reformacijos nuostata dèl gimtosios šnekamosios kalbos ir rašto vartojimo užtikrino Prūsijos lietuviams pradinio mokslo galimybę gimtąa kalba iki

(4) Prieiga per internetą: http://www.klein-litauen.de/front_content.php

(5) $2010 \mathrm{~m}$. buvo rastos Antrojo pasaulinio karo pabaigoje užkastos Piktupènų (dab. Pagègių savivaldybè) evangelikų liuteronų parapijos bažnytinès knygos, įrodančios, jog tokios „užkastos istorijos“ atvejų viso krašto mastu gali būti ir daugiau $[61 ; 64]$.

(6) Epitafija - tai užrašas antkapyje pagerbiant mirusijit. Joje būna užrašyta mirusiojo metrika ir kiti žodžiai.

(7) Panaudoti Vanagu evangeliku liuteronu bažnyčios archyvo 6-os bylos paskiri duomenys [37]. Konfesinio paveldo fiksavimo naujausius tyrimus žr. [22]. 
XIX a. paskutinio ketvirčio“ [44, 20], leido lietuviškų knygų spausdinimą ir lietuvių kalbos funkcionavimą kasdieninejje ir viešojoje erdvejje, ypač išskiriant bažnytinę aplinką. Lietuvių kalbos viešos panaudos situacija keičiasi po 1871 m., kai susikuria Vokietijos imperija, kurios vykdytos germanizacinès politikos metu „vokiečių nacionalizmas <...> èmé skleistis visu aktyvumu, - kartu buvo ir stipriausios lietuvių akultūracijos bei asimiliacijos laikotarpis“ [40, 135], mažinęs lietuviškai kalbančių gyventojų skaičių. Vokietijos imperijos metais atlikti gyventojų surašymai yra detaliausias šaltinis, atspindintis tautinę valstybès charakteristiką ir braižantis įvairiakalbị reicho žemèlapi. Nuo 1890 iki 1910 m. vykdytų gyventojų surašymų metu tautiškumo nustatymo kriterijumi buvo pasirinkta gimtoji kalba $[57,159]$. Nesigilinant ị lietuvių kaip gimtosios kalbos nurodymo problemiškumą (8), galima teigti, jog ị mūsų erdvės lauką patenkančioje teritorijoje fiksuotos lietuvių ir vokiečių grupès. Pažymėtina, kad tarp lietuvininkų tam tikrą dalị sudarẻ dvi gimtąsias kalbas nurodžiusieji. Tokie galimi precedentai buvo nurodyti ir surašinètojams parengtuose paaiškinimuose teigiant, jog „kiekvienas žmogus turi tik vieną kalbą, kuri jam sklandžiausia ir kurioje jis galvoja. Dvi gimtąsias kalbas teturi tik mažas žmonių skaičius; bet tokių atsitikimų gali pasitaikyti pas asmenis, kurie kilę iš tèvų su skirtingomis kalbomis" $[57,160]$. Lietuvininkų, kuriuos vokiečių tyrẻja Ulla Lachauer ịvardija dviejų tautų (vokiečių ir lietuvių Didžiojoje Lietuvoje - S. P.) sandūros regionine grupe $[27,66]$, atveju dvikalbiškumas buvo suformuotas politinès, sociokultūrinès prūsiškos / vokiškos aplinkos. Ši grupè, veikiama išorinių ir vidinių veiksnių, patyrè akultūracinius, asimiliacinius, visuomenès modernizacijos procesus, kurie koregavo ar išryškino lietuvininkų tautines ir kultūrines raiškas. Dvikalbiškumas reiškèsi ivvairiose kasdienès aplinkos situacijose: tiek bendraujant šeimoje su artimaisiais (9), tiek renkant vaikams vardus (10), tiek statant antkapinius paminklus kapinèse artimiesiems, kuriems skirtose epitafijose dažniausiai atsispindi natūraliai suaugusi dviejų kalbų samplaika (11). Iki Pirmojo pasaulinio karo pabaigos viešojoje erdveje klaipédiškio, memelenderio, Klaipédos krašto sąvokos neegzistavo [66, 10]. Šių definicijų atsiradimui turejo itakos pasikeitusi politinė situacija po Pirmojo pasaulinio karo ir atskiro Klaipėdos krašto šiaurinèje Prūsijos Lietuvos dalyje su(si)formavimas.

Po Pirmojo pasaulinio karo baigties 1919 m. sausio mèn. pradžioje prasidejusioje taikos konferencijoje buvo sprendžiamas pokario naujosios Europos žemèlapio klausimas, susijęs ir su Vokietijos teritorijos apkarpymais. Po ilgų derybų 1919 m. birželio mẻn. pabaigoje pasirašytos Versalio taikos sutarties 28-as straipsnis skelbè apie šiaurinès Rytų Prūsijos dalies - Klaipėdos krašto - atskyrimą nuo Vokietijos, o 99-ame straipsnyje buvo užfiksuotas krašto perdavimas Antantès valstybių žinion [66, 10], kurių vardu kraštą iki 1923 m. pradžios administravo Prancūzija.

(8) Tai susiję su 1) surašymą atlikdavusiais asmenimis, daugiausia vokiečių tarnautojais, tarp jų ir mokytojais, kurie, palaikydami valstybės vykdomą politiką, stengdavosi pateikti didesnị vokiečių skaičių; 2) Prūsijos lietuviais, kurie mokèjo lietuvių ir vokiečių kalbas, bet dẻl vokiečių kalbos vartojimo prioriteto neretai užsirašydavo esantys vokiečiais arba nurodydavo dvi gimtąsias kalbas: vokiečių ir lietuvių. Plačiau žr. [36, 66-72].

(9) Chrestomatinis pavyzdys galètų būti Emilio Kraštinaičio, gimusio $1903 \mathrm{~m}$. Ragainès apskrityje, atsiminimai, kuriuose teigta: „<..> mūsų šeimoje, kaip ir daugelyje kitų, buvo ịprotis tik su tèvais kalbèti lietuviškai, o vaikai tarpusavyje kalbèdavo vien vokiškai“ $[26,573]$.

(10) Kaip pasakojo Erdmutė Gerolytė iš Vabalų kaimo (Šilutės apylinkès), „nors šeimoje kalbejo lietuviškai, vaikų vardai buvo Hansas, ir Augustas, Anna, Maria, Rutha ir Edmutè“ [27, 64].

(11) Apie Klaipėdos krašto kapinių antkapinių ịrašų dvikalbiškumą plačiau žr. [35]. 
Šio laikotarpio oficialios statistikos duomenimis, $1920 \mathrm{~m}$. rugsejjo mėnesị Klaipèdos krašte iš viso gyveno per 140000 gyventojų, daugiausia vokiečiai (66 650) ir lietuviai (64 290) [50, 270]. Vadinamuoju prancūzmečiu, arba Trimečiu laikotarpiu, nepaisant vykusių politinių peripetijų dèl krašto politinès ateities perspektyvų ir gana sudètingos ekonominès situacijos, vieša klaipédiškio vartosena nesusiformavo.

Situacija iš esmès pasikeičia po $1923 \mathrm{~m}$. sausio mènesio, kai po sẻkmingai suorganizuotos Lietuvos karinès akcijos Klaipėdos kraštas buvo prijungtas prie Lietuvos [55; 56], o 1924 m. gegužès $8 \mathrm{~d}$. buvo pasirašyta Klaipėdos krašto konvencija, iteisinusi autonominius Klaipėdos krašto priklausymo Lietuvai aspektus $[50,163]$. Nesigilinant i Klaipėdos krašto integracijos ị Lietuvą 1923-1939 m. specifiką, su tuo susijusius krašto ekonominès, kultūrinès raidos ypatumus, neretai paženklintus Vokietijos ir Lietuvos kovos dèl įtakos stiprinimo krašte ir jo gyventojų, reikia konstatuoti, jog būtent šis Klaipėdos krašto autonominis laikotarpis pagimdè klaipédiškio fenomeną. Pirmą kartą viešajame diskurse ši sąvoka pateikiama kartu su 1925 m. sausio 20 d. atlikto Klaipėdos krašto gyventojų surašymo duomenimis. Remiantis jais, iš 141645 tuo metu Klaipèdos krašte gyvenusių asmenų vokiečiais save įvardijo 64158 žmonès (45, 2\%), lietuviais - 37626 (26, 6\%), klaipèdiškiais - 34337 (24, 2\%) gyventojai $[50,267]$. Nesigilinant ị tiek tarpukariu, tiek po Antrojo pasaulinio karo lietuvių ir vokiečių mokslininkų skelbtus ideologiškai angažuotus šios definicijos komentarus ir aiškinimus [29, $8 ; 50,269 ; 65,55]$, galima teigti, jog ir šiuolaikinejje istoriografijoje nèra vienos klaipédiškio definicijos sampratos interpretacijos. Paminètina, jog pastaruoju metu ją, remdamasis teorinemis tapatybès konstravimo prieigomis, siekia atskleisti Vasilijus Safronovas, kuris teigia, jog surašymo duomenys „fiksuoja skirtingų tapatybių ideologijų reikšmių išsidèstymą konkrečioje viešojo bendravimo erdvejje suformuotoje konjunktūroje“, o klaipédiškis esą kategorija, išreiškusi „viešojo bendravimo erdvejje sukonstruotas reikšmes, su kuriomis vietinis gyventojas tam tikru metu galejo susitapatinti“ [39, 39; taip pat žr. 41, 48-50]. Tos reikšmès buvo susijusios su vokiška ir lietuviška praeities pažinimo ir interpretavimo tradicija, su šių dviejų kalbų viešojoje erdveje raiška, tarp kurių vokiškumo panauda kiekvienais autonominio laikotarpio metais, ypač po neapdairaus krašto lituanizacijos protrūkio 4-ojo dešimtmečio pradžioje, spartèjo akivaizdžiai pastebimu pagreičiu. Pasak A. Hermanno, „iki 1918 metų dauguma lietuvininkų dar buvo išlaikę savitą identitetą, bet paskui jiems liko tik du keliai, tapti vokiečiais, arba lietuviais. Trečio, savito, kelio ieškoti buvo jau beprasmiška. Lietuvininkai pasirinko jiems labiau pažistamą kelią i vokiškumą“ $[12,51]$.

1925 m. gyventojų surašymo duomenų statistika yra pateikiama tik pagal apskritis ir Klaipėdos miestą, nėra duomenų iš atskirų vietovių, tačiau apie jų tautiškumą sąlyginai galima spręsti pagal $1910 \mathrm{~m}$. Vokietijos imperijos metais atliktą gyventojų surašymą, kuris iš principo radikaliai nepakito ir po 1923 metų. 1910 m. duomenimis, iš trijų apskričių lietuviškiausia $(66,2 \%)$ buvo Klaipėdos apskritis (12), tokios tautiškumo tendencijos nepakito ir po 1923 m., kai lietuviškiausia išliko Klaipėdos apskritis (13), o klaipẻdiškių skaičius trijose apskrityje buvo beveik apylygis (14). Klaipédiškiu fenomeno raiška, absorbuojanti dvikalbę krašto tradiciją, atsispindi ir antkapinių paminklų epitafijose. Tenka pabrèžti, jog epitafijos negali būti laikomos absoliučiai patikimu, tautinę statistiką patvirtinančiu šaltiniu, kadangi po Antrojo pasaulinio karo sunykus ar

(12) Šilutés apskrities lietuviškumas sudare 58, 2\%, Pagègių apskrities - 44, 1\% [57, 190].

(13) Šilutès apskrities lietuviškumas sudare 30,3\%, o Pagègių - 22,2\%. [50, 268].

(14) Klaipèdiškiai Klaipèdos apskrityje sudarè 26,5\%, Šilutès apsk. - 25,3\%, Pagègių - 25,2\%. [50, 268]. 
sunaikinus didžiąją dali artefaktų Klaipėdos krašto senosiose kapinėse, šiandien fiksuojami paminklai ir ịrašai juose gali būti traktuojami tik kaip tam tikri hipotetiniai tautinių tendencijų reprezentantai. Atkreiptinas demesys, kad tam tikrą tarpukario laikotarpio epitafijų dalį sudaro įrašai baltose marmurinèse ar juodo stiklo lentelèse, ịtaisytose paminkluose be pamato, antkapyje. Deja, paveldo fiksacijos metu konstatuota, jog nemaža dalis tokių epitafinių lentelių arba visai yra sudaužytos, arba iš išlikusių dalių ne visada galima tiksliai rekonstruoti palaidoto asmens duomenis (vardą, pavardę, gyvenimo metus) - svarbiausius epitafijos dèmenis.

Kaip jau buvo minèta, epitafijose labai ryškiai atsispindi kalbinis bilingvizmas, kuris identifikuojamas arba kiekviena kalba atskirai parašytose epitafijose, arba lietuvių kalbos ịrašuose pastebima vokiečių kalbos įtaka. Iliustruojant šias ịžvalgas, galima panagrinėti keletą pavyzdžių iš Stragnų / Skèrių (Klaipėdos r.) kapinių medžiagos. 1905 m. surašymo duomenimis, kaime iš 167 asmenų lietuviai sudarẻ 82,6\% (138 gyventojai), vokiečių kalbą gimtąja nurodè 28 gyvenusieji [57, 244], tad galima manyti, kad vietovè turèjo išlaikyti lietuviškumo atspalvị ir tarpukario metais. Panagrinėjus iš tarpukario laikotarpio išlikusių ịrašų turini, absoliučių tautinès raiškos (lietuvių ar vokiečių tradicijai atstovaujama) išvadų negalètume padaryti, tačiau vokiečių kalbos poveikis tuometinei aplinkai akivaizdus (15). Epitafijų kalbą nagrinejjantys kalbininkai pažymi, jog „labiausiai vokiečių kalbos [yra] paveiktas asmenvardžių lygmuo" $[5,73]$, kai pavardžių formos yra rašomos be galūnès (pvz., Naujoks) arba moterų asmenvardžiams yra priskiriamos vyriškos pavardès (pvz., Withe, Matuttes).

Analogiškų pavyzdžių galima rasti ir kitose kapinėse fiksuotuose įrašuose - minimos Marie Kerschies (16), Madliene Kaitinnis (17), Lotte Kujus (18) ir kitos moteriškos lyties asmenims priskirtos vyriškos formos pavardès.

Dviejų kultūrinių tradicijų sankirtą reprezentatyviai iliustruoja ir dviejų šriftų - lotyniško ir gotiško - vienoje epitafijoje koreliacija, ir tai yra būdinga tiek vokiškos (19), tiek lietuviškos (20) kilmès asmenų antkapiniams įrašams. Galima teigti, jog tarpukario

(15) Kapas Nr. 13: Czion / ilsis Pakajuj / Mare Withe / ²6.11.1878 / †30.1.1938 / Ilsékis saldžiai.; kapo Nr. 39 epitafija: Czion ilsis / Dieweje mano / mÿlimas Wiers / ir muso / Tewas / Wilhelm Naujoks / ${ }^{\star}$ 10.6.1875, / †10.58.1929; kapo Nr. 44 pavyzdys: Czion ilsis Dieweje / mano mÿlima Motrieschke / bei muso Motinele / Urte / Matuttes / ². Juli 1872, / †6. April 1932. Stragnų / Skèrių kapinès, Klaipėdos r., Priekulès seniūnija. Duomenys saugomi KU BRIAI KKKSDB (Klaipèdos universiteto Baltijos regiono istorijos ir archeologijos instituto Klaipedos krašto kapinių skaitmeninè duomenų bazė).

(16) Čzion ilsis Dieweje / mano geroji Moteriszke / musu mülima Motinèle / Marie Kerschies / *16.5.1876 / †20.7?.1922 / ir mano mülims Sunus / musu Brolis / Walter. Lužų I kapinès, kapas Nr. 3, Klaipėdos r., Sendvario sen. Duomenys saugomi KU BRIAI KKKSDB.

(17) Hier Ruht in Gott / unsere liebe Mutter / Madliene Kaitinnis / ${ }^{\star} 1866$ - †1933. Lužų I kapinès, kapas Nr. 22. Klaipėdos r. Sendvario sen. Duomenys saugomi KU BRIAI KKKSDB.

(18) Hier ruhen in Gott / unsere lieben Eltern / Georg Kujus / *31.3.1847 †14.101918 / Lotte Kujus / geb.

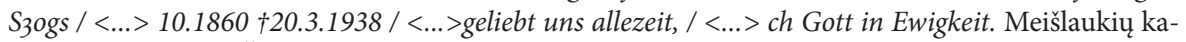
pinės, kapas Nr. 34, Šilutès r. Usėnų sen. Duomenys saugomi KU BRIAI KKKSDB.

(19) Hier ruhet in Gott / Frau / Mathilde Hess, [gotiškai] / geb. [Jo]rke, / *27.1.1866, †14.10.1937. / Ruhe fanft! Žagatpurvių I kapinès, kapas Nr. 29, Šilutès r., Švèkšnos sen. Duomenys saugomi KU BRIAI KKKSDB.

(20) Hier ruhet in Frieden [gotiškai] / mein lieber Mann, unser lieber Bruder / Georg Pa/3ehr, [gotiškai] / geb. 20. Juni 1873, geft. 10. Mai 1927. / Die Scheidestunde schlug zu früh, / Doch Gott, der Herr, bestimmte sie. / Ruhe sanft! Kavolių IV kapinès, kapas Nr. 37, Šilutès r., Usènų sen. Duomenys saugomi KU BRIAI KKKSDB. 
laikotarpio epitafijos reprezentatyviai atspindi klaipédiškio fenomeną, kai ne tautybè ir ne pavardès kilmė nulèmė tautines nuostatas, o tam tikros viešojoje bendravimo erdvèje sukonstruotos reikšmès, kurių dèka „visą tarpukarị gyventojų provokiška orientacija Klaipėdos krašte buvo palaikoma apibrèžiant savo priklausomybę ir atskirumą per priklausomybę regionui išreiškusias sąvokas (Memelländer <...>), bendros tèviškès (Heimat), bendros praeities, bendros kultūros $<\ldots>$ simbolius ir vaizdinius" $[39,64]$. Epitafijų kalbinè raiška galèjo būti kaip tik ta reikšmè, kuri simbolizavo akivaizdų ligi tol vyravusios krašto kalbinès ir laidojimo tradicijos tęstinumą.

Analizuojant epitafijų kalbą ir turinị 1939-1944 m., atkreiptinas dėmesys, jog po 1939 m. ịvykdyto Klaipėdos krašto anšliuso „buvo sustabdytas lietuviškų laikraščių išleidimas“, o klaipédiškiai pateko ì "griežtą vokietinimo politiką tautinių mažumų atžvilgiu“ [7, 159], kai lietuvių kalbos viešas vartojimas buvo uždraustas net bažnyčiose, o už lietuviškų radijo laidų klausymą buvo baudžiama baudomis [17, 28]. Provokiška nuostata atsispindèjo ir laidojimo bei kapinių kultūroje. Negausios šio laikotarpio užfiksuotos epitafijos liudija išimtinai vokišką ịrašų kalbą (21), kuri suniveliuoja visus krašto gyventojus ị tik vokiškumu grịstą monolitą.

Pavieniai antkapiniai paminklai (22) kritusiems Wermachto kariams demonstruoja griežtai reglamentuotą Trečiojo reicho metais pranešimų apie karių mirtị kalbinị trafaretą, kuris buvo privalomas visoje Reicho teritorijoje skelbiant žinias apie žuvusiuosius „už fiurerị bei tèvynę" [33, 350-356]. Tokių vienodos struktūros žinučių gausu to meto leistuose laikraščiuose, Klaipėdos krašto tyrëjams yra aktuali dienraštyje Memeler Dampfboot skelbta informacija, kurią galima būtų naudoti ateities tyrimams apie Klaipèdos krašto gyventojus, kariavusius Antrajame pasauliniame kare.

Fragmentiniai 1939-1944 m. epitafijų pavyzdžiai liudija, jog vietos gyventojų tautinè ir kultūrine raiška buvo aiškiai ịsprausta ị nacistinès Vokietijos vykdytos tautinès politikos rèmus, tad bet kokios ne vokiečių kalbos viešo naudojimo (mūsų tiriamuoju atveju - kapinių kultūroje) galimybės buvo neįmanomos.

Nagrinėjant klaipėdiškių tautinę ir kultūrinę raišką po Antrojo pasaulinio karo, atkreiptinas dèmesys, jog istoriografinèje apyvartoje ịvairuoja vietinius krašto gyventojus îvardijanti definicija: vietiniai gyventojai [14], senieji gyventojai [4], klaipédiečiai [15], klaipėdiškiai $[11 ; 17]$. Pažymètina, kad nè viena sąvoka neapibrèžia tautiškumo, o išskiria šios gyventojų kategorijos priskyrimą tam tikram teritoriniam regionui, jų vietininkiškumą. Nesigilindami it Klaipèdos krašto vietos gyventojų pilietybės ir tautybès santyki pokario metais [11] pažymėsime, kad šio tyrimo kontekste mums yra aktualus klaipédiškio kaip tam tikro pokario istorijos subjekto saviidentifikavimas pasikeitusiomis

(21) Hier ruht in Gott / Maria Hasenhein / ${ }^{\star 29.5 .1865 ~ \$ 12.2 .1940 . ~ K a v o l i u ̨ ~ I I ~ k a p i n e ̀ s, ~ k a p a s ~ N r . ~} 10$. Šilutès r., Usėnų seniūnija. Duomenys saugomi KU BRIAI KKKSDB.; Hier / ruhen in Frieden / Robert Borm / ${ }^{*}$ 14.7.1861 †22.3.1941 / Pauline Borm / geb. Brokopp / <..> 9.1858 †29.3.1941 Uostiškių kapinès, kapas Nr. 3, Šilutès r., Usènų seniūnija. Duomenys saugomi KU BRIAI KKKSDB.; Hier / ruh <...> Frieden / Hein <...> Peldszus / ${ }^{\star} 15.7 .1876 . ~ † 28.7 .1940$ / Lydia Peldszus / ${ }^{\star} 16.2 .1922$ †19.10.1940. / Es war, o Herr, dein Wille. Meišlaukių kapinès, kapas Nr. 19, Šilutès r., Usènų sen. Duomenys saugomi KU BRIAI KKKSDB.; <...> / ruht in Gott / Maria Uigschies / geb. Jurat verw. Endrejat / ${ }^{\star} 18.9 .1858$ †9.7.1940. / Christus ist mein Leben. Katyčių II kapinès, Šilutès r., Katyčių sen. Duomenys saugomi KU BRIAI KKKSDB.

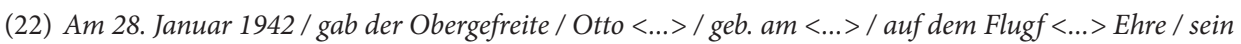
Leben für Führer, / Volk und Vaterland. Katyčių II kapinès, Šilutès r., Katyčių sen. Duomenys saugomi KU BRIAI KKKSDB. 
istorinėmis aplinkybėmis, kai „vokiečių nacionalistinè tapatybės ideologija, kuri ikikarinėje Klaipėdoje buvo pagrindinė prolietuviškos tapatybės ideologijos konkurentė, prarado savo konkurencinị pagrindą“ $[41,181]$. Anot V. Safronovo, tokius tapatybès pokyčius nulèmė Sovietų Sąjungos politikos neribota antivokiška propaganda ir 1944-1945 m. sandūroje daugumos senụjų krašto gyventojų, kurie galejjo būti Lietuvai nelojalūs ir besiorientuojantys ì Vokietiją, praradimas [41, 181-182]. Iš principo sutinkant su antruoju autoriaus teiginiu, tenka pažymèti, kad nors likusieji vietiniai Klaipèdos krašto gyventojai ir sudare tik nedidelę pokario krašto gyventojų dalį, visgi jų negalima išeliminuoti ir to meto viešosios aplinkos. Telkimasis $\mathfrak{i}$ atskiras, daugiausia religiniu pagrindu susietas bendruomenes liudija jų, kaip mažumos grupès, santykị su naująja gyventojų dauguma ir nagrinètinas kaip atskiras to meto viešojo diskurso segmentas.

Siekiant atskleisti tam tikras klaipediškių tautinès ir kultūrinès raiškos formas ir tendencijas, pasirinkti vienos evangelikų liuteronų parapijos, Vanagų, priklausančios Klaipėdos rajonui, mikrotyrimo socialiniai-kultūriniai pjūviai. Straipsnyje nèra aktualu atskleisti šios bažnyčios ir parapijos istoriją, čia, remiantis konfesinio paveldo fiksavimo medžiaga, dèmesys sutelkiamas ị parapijiečių tautines raiškas. Kaip pagalbinẻ tema analizuojama klaipėdiškių statistine išraiška: pasirinkus vieną parapiją lyginama bažnytinių knygų bei senosiose Klaipėdos krašto kapinèse išlikusių epitafijų informacija. Tokių duomenų analizė yra reikšminga keliais aspektais: pirma, ji rodo, kokios kapinės pokario metais buvo naudojamos kaip veikiančios - tai atskleistų atskirų vietovių kaip klaipėdiškių branduolių gyvybingumą; antra, kapinèse išlikusios epitafijos, liudijančios apie čia palaidotuosius po 1945 m., leidžia daryti santykines išvadas apie klaipediškių tautinę raišką ir ikikarinès kultūrinès tradicijos tąsą pokario aplinkoje.

1903 m. ịkurtai Vanagų parapijai priklausė 14 kaimų ir du dvarai (23). Pastaruoju metu šios vietovès priklauso Klaipėdos ir Šilutès rajonams. Šiuose kaimuose, remiantis kultūros vertybių registro duomenimis (24) ir konfesinio paveldo fiksavimo medžiaga, užfiksuota 17 kapinių, kadangi pagal XVIII-XIX a. kapinių steigimo Prūsijoje tradiciją kapines turèjo kiekvienas kaimas, o „nereta gyvenvietė turejjo po kelerias kapines“ [6, 234]. Minimoje Vanagu parapijoje po dvejas kapines turèjo Pozingių, Stankaičių, Stonaičių kaimai, trejos kapinès buvo Kantvainiuose. Nors žinoma tik reliatyvi statistika apie parapijos dydį iki Antrojo pasaulinio karo pabaigos (25), bažnytiniai duomenys po $1945 \mathrm{~m}$. leidžia teigti, jog nepaisant pirmaisiais pokario metais sutelktos pakankamai gausios parapijos bendruomenès (26), tiek siauresniame, parapijos, tiek platesniame, viso Klaipėdos krašto, kontekste turime kalbèti apie didesnès klaipėdiškių dalies praradimą.

(23) Parapijai priklausė Vanagų, Poškų, Agluonėnų, Kantvainių, Žydelių, Žagarų, Šauklių, Ažpurvių, Péžaičių, Pozingių, Dvylių, Dèglių, Stankaičių, Stonaičių kaimai bei Aisennų ir Blymačių dvarai [34, 95-97].

(24) Klaipèdos rajono kultūros vertybių registro duomenis žr:: http://kvr.kpd.lt/heritage/Pages/ ResultPrint.aspx

(25) Išeivijoje leisto lietuviško laikraščio Lietuvos pajūris duomenimis, $1911 \mathrm{~m}$. Vanagų parapijoje buvo 2520 gyventojų [34, 98].

(26) Nuo 1945 m. pamaldas bažnyčioje laikęs $1950 \mathrm{~m}$. ị kunigus įšventintas Jurgis Sprogys $1949 \mathrm{~m}$. sudare Vanagų parapijiečių sąrašą, kuriame yra apie 1200 pavardžių. Sąraše pateikti asmenų vardai, pavardès, tèvavardžiai, gimimo data ir gimimo vieta, tuometinè gyvenamoji vieta, krikštijimo, sutuoktuvių data ir itin vertingas pastabų arba skyrelis apie mirti. Jame pateikta parapijiečio mirties, ištrèmimo ị Sibirą arba išvykimo ị Vokietiją data [59, 1-45a.]. 
Mūsų tiriamai temai yra svarbi mirusių parapijiečių statistika, jų palaidojimo vietos lokalizacija, išlikusių antkapinių paminklų ir jų ịrašų identifikacija. Svarbiausiu ir vieninteliu rašytiniu šaltiniu, leidžiančiu nustatyti mirusius parapijiečius po 1945 m., yra mirusių parapijiečių sąrašai [59, 50-100], kuriuose buvo užrašomas mirusiojo vardas ir pavardè, jo amžius, gyvenamoji vieta ir kokiose kapinèse jis palaidotas. Pastaroji informacija yra svarbi, nes, palyginus ją su konfesinio paveldo fiksavimo metu gautais duomenimis, daromos išvados, kiek išlikę antkapiniai paminklai ir įrašai kapinèse atspindi realiai atskirose kapinėse po 1945 m. palaidotų asmenų skaičių.

Kunigas Jurgis Sprogys 1946-1960 m. palaidojo 361 klaipèdiškį, iš jų 203 Vanagu parapijai priklausiusiose kapinèse [59, 50-63]. Kadangi J. Sprogys aptarnavo ir Kintų, Saugų bei Plikių parapijas [43], tai likusieji mirę asmenys buvo palaidoti ịvairiose šių parapijų kapinèse. Atkreiptinas dèmesys, jog kunigo Sprogio surašytas sąrašas neturètų būti vertinamas kaip baigtinis ir absoliučiai patikimas šaltinis, nes, remiantis sakytinès istorijos liudijimais (27) ir tik Kantvainių kaimo dvejų kapinių epitafijų statistikos analize (28), galima konstatuoti, jog ne visi parapijiečiai šiuo laikotarpiu buvo laidojami J. Sprogio. Šias apeigas pirmaisiais pokario metais trūkstant krašte kunigų atliko surinkimininkų tradicijas išlaikę sakytojai, kurie po Antrojo pasaulinio karo pasiliko Klaipėdos krašte ir „karui einant ì pabaigą atnaujino savo darbą“" $[10,38]$. Kaip teigiama Vanagų bažnyčios istorijoje po 1945 m., pirmos pamaldos čia įvyko 1945 m. kovo mènesį. Jas laikè sakytojas Jurgis Kilius iš Vanagų: „nuo pat kovo mėnesio pasikeistinai pamaldas Bažnyčioj nulaikè broliai Sakytojei, Killius Jurgis [iš] Vanagų, Kibelka Adomas [iš] Čiutelių, Kuršys Jonas [iš] Čiutelių ir Skudis Jurgis [iš] Čiutelių." Pirmas pamaldas kantorius J. Sprogys laikè $1945 \mathrm{~m}$. rugsejjo 18 d. [58, 2]. Norint surinkti išsamiausią informaciją apie pokario klaipediškius, reiketų disponuoti ne tik kunigų, bet ir sakytojų fiksuotais duomenimis, kurių neįmanoma identifikuoti.

Iš Vanagų parapijos kapinių kaip tyrimo objektas yra pasirinktos Agluonėnų, Dėglių, Dvylių, Kantvainių, Stankaičių, Ašpurvių, Stonaičių kaimų kapinès, kuriose, pagal bažnytinius dokumentus, buvo palaidota 111 asmenų (29).

Žinant palaidotų asmenų minètose kapinėse skaičių ir disponuojant konfesinio paveldo fiksavimo medžiaga, galima apibendrinti, kiek kapinėse esantys antkapiniai paminklai ir juose išlikusios epitafijos yra reprezentatyvios atskleidžiant klaipediškių istoriją 1945$1960 \mathrm{~m}$. atskirose vietovèse.

(27) Erna Rimerytė-Filozienè, gim. 1923 m. gegužès 8 d., teigè, kad jos tèvas Friedrichas Wilhelmas Rimeris, miręs apie 1946-1947 m., yra palaidotas Kantvainių kaimo kapinėse. F. W. Rimeris nèra pažymètas J. Sprogio mirusių parapijiečiu sąraše, kapinèse nèra ir jam skirto antkapinio paminklo (2013 m. rugpjūčio 2 d. užrašyti atsiminimai saugomi autorès asmeniniame archyve).

(28) Remiantis mirusiųjų sąrašu, Kantvainių kaimo dvejose kapinèse 1946-1960 m. buvo palaidoti 27 gyventojai. Šiuos duomenis palyginus su išlikusiomis kapinėse epitafijomis, konstatuojama, kad šiuo laikotarpiu kapinèse palaidoti 7 asmenys nebuvo ịtraukti ị mirusiu parapijiečių sąrašą: tai Ewa Ilginnis (mirè 1947 m.), Gerhard Broszeitis (mirè 1951 m.), K. Slizis (mirè 1948 m.), Michel Purwins (mirè $1946 \mathrm{~m}$.), Eduard Garde (mirè $1949 \mathrm{~m}$.), Marie Bandze (mirè 1959 m.), Elzè Stalgytè (mirè 1949 m.) [34, 142-150]; Kantvainių kaimo kapinių konfesinio paveldo fiksavimo medžiaga. Duomenys saugomi KU BRIAI KKKSDB.

(29) Agluonènų kapinėse palaidota 11 žmonių, Dėglių - 32, Stankaičių (dvejos kapinès) - 9, Ažpurvių - 14, Dvylių - 12, Stonaičių (dvejos kapinès) - 6, Kantvainių dvejose kapinèse - 27 žmonès [59, 50-63]. 
Lentelè. Palaidotų asmenų ir išlikusių epitafinių irašų santykis atskirose Vanagų parapijos kapinėse

\begin{tabular}{|c|c|c|c|c|c|c|c|c|}
\hline & $\begin{array}{c}\text { Agluo- } \\
\text { nènai }\end{array}$ & $\begin{array}{c}\text { Ažpur- } \\
\text { viai }\end{array}$ & Dégliai & Dvyliai & $\begin{array}{c}\text { Kant- } \\
\text { vainiai }\end{array}$ & $\begin{array}{c}\text { Stan- } \\
\text { kaičiai }\end{array}$ & $\begin{array}{c}\text { Stonai- } \\
\text { čiai }\end{array}$ & $\begin{array}{c}\text { Ǐ̌ } \\
\text { viso }\end{array}$ \\
\hline $\begin{array}{c}1945-1960 \text { m. pa- } \\
\text { laidotuju kapinėse } \\
\text { skaičius (bažnyčios } \\
\text { duomenys) }\end{array}$ & 11 & 14 & 32 & 12 & 27 & 9 & 6 & 111 \\
\hline $\begin{array}{c}\text { Kapinése fiksuotu } \\
\text { epitafiju, liudijančiu } \\
\text { apie šiuo laikotarpiu } \\
\text { palaidotuosius, } \\
\text { skaičius }\end{array}$ & $7(30)$ & $7(31)$ & $7(32)$ & $0(33)$ & $11(34)$ & $6(35)$ & $1(36)$ & 39 \\
\hline $\begin{array}{c}\text { Procentine epitafiju } \\
\text { apie palaidotuosius } \\
\text { išraiška }\end{array}$ & $64 \%$ & $50 \%$ & $21,8 \%$ & $0 \%$ & $40,7 \%$ & $66,6 \%$ & $16,6 \%$ & $35,5 \%$ \\
\hline
\end{tabular}

Gauti rezultatai leidžia teigti, jog kapinėse užfiksuoti artefaktai pateikia tik daugiau kaip trečdalị informacijos apie pokario metais kapinėse palaidotus klaipėdiškius. Tokia tendencija paaiškintina dviem aspektais: pokariu dèl sunkios ekonominès situacijos, taip pat daliai klaipédiškių 1958-1960 m. išvykus gyventi ị Vokietiją, dalis kapaviečių nebuvo paženklinta jokiu antkapiniu paminklu; iš antkapinių paminklų, pokariu statytų kapinėse, išskirtini iki metro aukščio ir žemesni mediniai kryžiai, kurių dauguma per keletą dešimtmečių visiškai sudūlejjo, todèl nebeįmanoma nustatyti ir juose įrèžtos informacijos. Galima teigti, kad geriausiai įskaitomi įrašai yra pokario metais statytuose cementiniuose paminkluose, kuriuose raidès buvo įrèžiamos arba horeljefinès, taip pat metalinėse epitafinèse lentelèse, pritvirtintose prie kaltinių ar medinių kryžių.

Nagrinejjant pokario laikotarpio klaipėdiškių istoriją, svarbu pateikti ir jų tautinès raiškos sampratą, kuri atskleidžia vietinių Klaipedos krašto gyventojų ankstesnès kultūrinès / tautinès tradicijos tęstinumą, daugiausia susijusị su religine, laidotuvių tradicija. Antkapinių paminklų įrašai išryškina kelis šimtus metų Klaipėdos krašte tarpusią dvikalbystę. Galima manyti, kad vokiška kalbinė raiška epitafijose pokario metais buvo labai ryškus klaipèdiškių savo / kitokios bendruomenès, skirtingos nuo atsikèlusių iš Didžiosios Lietuvos, identifikavimo kriterijus. Nors liuteronų „bažnyčia vartojo tik lietuvių kalbą ir tik atskirais atvejais, krikštijant arba suteikiant ligoniui paskutinę šv. vakarienę, vartota ir vokiečių kalba, jei tikintysis lietuviškai nemokejo“ [11, 87-90], kai kurie viešojoje erdvejje reprezentuoti religinio gyvenimo ženklai turejjo išreikšti čia gyvenusių klaipediškių kitokią savastị ir tam tikrą kultūrinę bei tautinę atskirtị nuo pokariu susidariusios gyventojų daugumos. Atlikus išlikusių 39 antkapinių įrašų (1945-1960 m.) kalbinę analizę gauti tokie rezultatai: lietuviškos epitafijos sudaro $43,5 \%$, vokiškos - 38,5\%, dvikalbès - 17,9\% (lentelè).

(30) Agluonėnų kapinių fiksavimo (2006 m., tikslinti 2013 m.) duomenys saugomi KU BRIAI KKKSDB.

(31) Ažpurvių kapinių fiksavimo (2006 m., tikslinti 2013 m.) duomenys saugomi KU BRIAI KKKSDB.

(32) Dėglių kapinių fiksavimo (2012 m.) duomenys saugomi KU BRIAI KKKSDB.

(33) Dvylių kapinių fiksavimo (2006 m., tikslinti 2013 m.) duomenys saugomi KU BRIAI KKKSDB.

(34) Kantvainių kaimo I ir II kapinių fiksavimo (2013 m.) duomenys saugomi KU BRIAI KKKSDB.

(35) Stankaičių kaimo I ir II kapinių fiksavimo (2011 m.) duomenys saugomi KU BRIAI KKKSDB.

(36) Stonaičių kaimo I ir II kapinių fiksavimo (2012 m.) duomenys saugomi KU BRIAI KKKSDB. 
Prie dvikalbių epitafijų buvo priskirti tokie įrašai, kuriuose tekstas Čion ilsis, ilsèkités ramybèje etc. buvo pateikiamas lietuvių kalba, o vardai ir pavardès užrašyti vokiškai, pvz., „Cion ilsis mūsu Tewai / FRANZ HEYDECK / ${ }^{\star} 10.6 .1882$ / †4.2.1953 / EVA HEYDECK / * 10.3.1891 / †25.8.1950 / Ilsẻkitès ramybėje“ (37). Epitafijų rašymas vokiečių kalba (arba tik pavardžių ir vardų) fiksuojamas visais pokario dešimtmečiais (38).

Pažymėtina, kad vokiškų įrašų būta ir laidotuvių vainikų kaspinuose, kurie ịamžinti pokario metais vykusių laidotuvių nuotraukose, pvz., Anos Laukstėnienès iš Sakūtèlių (Šilutès r.) laidotuvèse $1956 \mathrm{~m}$. vasario 24 d. Sakūtèlių kapinėse ant laidotuvių vainikų kaspinų matyti ịrašai: „<...> in / dem / Herrn / sterben / <..> von / Ehegatten, / Kindern, / und / Enkelkindern“" (39). Pasirinktą chronologinę tyrimo pabaigos ribą ties 1960 m., kaip tam tikrą klaipèdiškių būties marginalizavimosi cezūrą, iliustruoja mirusių klaipėdiškių sumažejimas, nes minètoje parapijoje 1961-1980 m. užrašyta 140 mirusių parapijiečių pavardžių [59, 64-70a.], t. y. 2,5 karto mažiau nei 1946-1960 metais. Tad akivaizdu, kad iki 1960 m. reprezentatyviau yra atspindima klaipédiškių tautine raiška, kurią iliustruoja Klaipėdos krašto senosiose kapinèse esančios epitafijos.

Apibendrinant šio tyrimo rezultatus galima teigti, jog pasitelkiant daugiasluoksnę šaltinių bazę, kurioje svarbiausią dali sudaro konfesinio paveldo artefaktuose išlikusios epitafijos, galima daryti tam tikras ịžvalgas apie klaipédiškių tautines ir kultūrines raiškas XX amžiuje. Klaipėdiškio definicija, atsiradusi tarpukario Klaipėdos krašto viešojoje erdvèje, apibrèžiama kaip tapatybès konstravimo reikšmė, susijusi su lietuviška ar vokiška praeities pažinimo tradicija ar interpretacija. Epitafijų analizė leidžia teigti, jog tarpukariu aiškiai išreikštas lietuvių ir vokiečių kalbų bilingvizmas simbolizavo akivaizdų ligi tol vyravusị krašto kalbinès ir laidojimo tradicijos tęstinumą.

Fragmentiniai 1939-1944 m. epitafijų pavyzdžiai liudija, jog vietos gyventojų tautinè ir kultūrinè raiška buvo aiškiai įsprausta ị nacistinès Vokietijos vykdytos tautinès politikos rèmus, tad bet kokios ne vokiečių kalbos viešo eksploatavimo, mūsų tiriamuoju atveju - kapinių kultūroje, galimybès buvo neįmanomos.

Pokario laikotarpio klaipėdiškių tautinès raiškos samprata atskleidžia vietinių Klaipėdos krašto gyventojų ankstesnès kultūrinès / tautinès tradicijos tęstinumą, daugiausia susijusị su religine, laidotuvių tradicija.

Nepaisant sovietiniais metais vestos griežtos ateizmo politikos, liuteronų bažnyčia buvo svarbi regioninès istorijos dalis, saugojusi klaipėdiškių savitą identitetą. Tai reprezentatyviai atspindi epitafijos, kuriose susiliejusios vokiečių ir lietuvių kalbos iliustruoja iki Antrojo pasaulinio karo pradžios krašte vyravusios dvikalbės tradicijos tąsą ir klaipèdiškių tautinę bei kultūrinę raišką pasikeitusioje politinèje ir socialinejje aplinkoje pokario metais. Tai buvo labai ryškus klaipėdiškių savos / kitokios bendruomenès, skirtingos nuo atsikèlusių iš Didžiosios Lietuvos pokario metais, identifikavimo kriterijus.

Gauta 20130930

Priimta 20131210

(37) Dėglių kapinių (Šilutės r., Saugų sen.) kapas Nr. 64. Duomenys saugomi KU BRIAI KKKSDB.

(38) Hier ruht in Frieden / meine liebe Gattin / u. Mutter / Marie Bolz / *9.8.1886. †19.8.1970. Dėglių kapinių (Šilutės r., Saugų sen.) kapas Nr. 93. Duomenys saugomi KU BRIAI KKKSDB.; Hier ruhet in Frieden / unser liebes Söhnchen / mein Bruderchen / Günter Matzpreiksch / ^9.4.1980 / †21.6.1980. Čiūtelių kapinių (Šilutès r., Saugų sen.) kapas Nr. 3. Duomenys saugomi KU BRIAI KKKSDB.

(39) Informacija iš KU BRIAI projekto „Šeimos albumų istorijos. Klaipèdiškiai 1944-1960 m.“ duomenų bazès. 


\section{Literatūra ir šaltiniai}

[1] Antrojo pasaulinio karo pabaiga Rytų Prūsijoje: faktai ir istorinès ǰžvalgos. Acta historica universitatis Klaipedensis. T. XVIII. Sudarė A. L. Arbušauskaitė. Klaipėda: Klaipėdos universiteto l-kla, 2009. 350 p.

[2] ARBUŠAUSKAITÉ, Arūnè, Liucija. Anšliusas ir Klaipedos krašto gyventojai (1939-1944). Klaipeda: Klaipèdos universiteto l-kla, 2010. 311 p.

[3] ARBUŠAUSKAITĖ, Arūnè, Liucija. Klaipèdos krašte nèra nė vienos šeimos, iš kurios nebūtų kas nors atimta. Iš: Antrojo pasaulinio karo pabaiga Rytų Prūsijoje: faktai ir istorinès ǰžvalgos. Acta historica universitatis Klaipedensis. T. XVIII. Sudarè A. L. Arbušauskaitè. Klaipèda: Klaipėdos universiteto 1-kla, 2009, p. 322-330.

[4] ARBUŠAUSKAITĖ, Arūnè, Liucija. Kuršių nerijos gyventojų socialiniai-demografiniai pokyčiai. Iš: Lietuvininkų kraštas. Kaunas: Litterae universitatis, 1995, p. 372-397.

[5] BALČIŪNIENĖ, Asta. Klaipedos krašto liuteroniškų kapinių paminkliniai įrašai lingvistiniu aspektu. Iš: Klaipėdos krašto konfesinis paveldas: tarpdisciplininiai senujų kapinių tyrimai. Acta historica universitatis Klaipedensis. T. XXV. Sudarė S. Pocytė. Klaipėda: Klaipėdos universiteto 1-kla, 2012, p. 62-76.

[6] BARASA, Darius. Senosios Šilutès krašto kapinės - archyvai po atviru dangumi. Iš: Mažosios Lietuvos kultūros paveldas. Vilnius: Vilniaus universiteto l-kla, 2006, p. 232-239.

[7] BUBNYS, Arūnas. Lietuvos interesų gynimas Klaipėdos krašte 1939-1940 metais. Iš: Klaipédos krašto aneksija 1939 m.: politiniai, ideologiniai, socialiniai ir kariniai aspektai. Acta Historica universitatis Klaipedensis. T. XXI. Sudarè S. Pocytè. Klaipėda: Klaipėdos universiteto 1-kla, 2010, p.157-174.

[8] BUKAVICKAS, Rubenas. Šilutès apskrities kūrimas ir jos sovietizacija 1945-1950 metais. Magistro baigiamasis darbas, 2012. Klaipédos universiteto Baltijos regiono istorijos ir archeologijos instituto archyvas.

[9] Erdviu pasisavinimas Rytu Prūsijoje XX a. Acta historica universitatis Klaipedensis. T. XXIV. Sudarè V. Safronovas. Klaipėda: Klaipèdos universiteto l-kla, 2012. 357 p.

[10] GENYS, Mindaugas. Lietuvos evangelikų liuteronų bažnyčios padètis sovietinès okupacijos metais 1940-1990 metais. Magistro baigiamasis darbas, 2004. Klaipédos universiteto Baltijos regiono istorijos ir archeologijos instituto archyvas.

[11] HERMANN, Arthur. Klaipèdiškių likimas Lietuvoje po 1945 m. Iš: A. Hermann. Lietuvių ir vokiečiu kaimynyste. Vilnius: Baltos lankos, 2000, p. 73-94.

[12] HERMANN, Arthur. Lietuviškumo problema Rytų Prūsijos evangelikų bažnyčioje 18711933. Iš: A. Hermann. Lietuvių ir vokiečių kaimynystė. Vilnius: Baltos lankos, 2000, p. 50-72.

[13] JUŠKA, Albertas. Mažosios Lietuvos bažnyčia XVI-XX amžiuje. Klaipėda: Klaipėdos universiteto l-kla, 1997.

[14] KAIRIŪKŠTYTĖ, Nastazija. Klaipedos krašto kaimo vietovių apgyvendinimas pokario metais. Iš: Lietuvininkų kraštas. Kaunas: Litterae universitatis, 1995, p. 339-371.

[15] KAIRIŪKŠTYTĖ, Nastazija. Klaipėdos krašto repatriantai ir jų padètis 1945-1950 m. Lituanistica, 1991, Nr. 2(6), p. 35-48.

[16] KAUNAS, Domas. Mažosios Lietuvos knygų link. Vilnius: Vilniaus universiteto 1-kla, 2013. 279 p.

[17] KIBELKA, Ruth. Memelland. Fünf Jahrzehnte Nachkriegsgeschichte. Berlin, 2002. 238 S.

[18] KIBELKA-LEISEROWITZ, Ruth. Parodos „Šeimos albumu istorija(os): klaipédiškiai 19441960 m. " ivadinis žodis. Klaipedos universiteto Baltijos regiono istorijos ir archeologijos institutas, 2006. 
[19] Klaipédos kraštas 1920-1924 m. archyviniuose dokumentuose. Acta historica universitatis Klaipedensis. T. IX. Sudare S. Pocytè. Klaipèda: Klaipèdos universiteto l-kla, 2003. 160 p.

[20] Klaipédos krašto aneksija 1939 m.: politiniai, ideologiniai, socialiniai ir kariniai aspektai. Acta historica universitatis Klaipedensis. T. XXI. Sudare S. Pocytè. Klaipeda: Klaipedos universiteto l-kla, 2010. $253 \mathrm{p}$.

[21] Klaipédos krašto istorijos ir kultūros atodangos. Klaipédos karšto visuomenès veikejjui Adomui Brakui atminti. Sudare K. Jokubavičienė, S. Pocytė. Klaipėda: Klaipèdos universiteto 1-kla, 2007. $165 \mathrm{p}$.

[22] Klaipedos krašto konfesinis paveldas: tarpdisciplininiai senuju kapiniu tyrimai. Acta historica universitatis Klaipedensis. T. XXV. Sudare S. Pocytè. Klaipèda: Klaipèdos universiteto l-kla, 2012. $301 \mathrm{p}$.

[23] Klaipėdos krašto prisiminimai. Klaipèda: S. Jokužio leidykla-spaustuve, 2009. 126 p.

[24] Konfirmantų sąrašų knyga 1945. Vanagu evangeliku liuteronu bažnyčios archyvas, b. 9.

[25] KOSSERT, Andreas. Ostpreußen. Geschichte und Mythos. Pantheon, 2007.

[26] KRAŠTINAITIS, Emilis. Mažoji Lietuva, kokia ji buvo paskutiniuoju laiku. Iš: Lietuvininku žodis. Kaunas, 1995, p. 573-610.

[27] LACHAUER, Ulla. Rytprūsiški likimai. Vilnius: Baltos lankos, 2004.

[28] LACHAUER, Ulla. Rojaus kelias: Rytprūsiu ūkininkès Lènès Grigolaitytès prisiminimai. Vilnius: Baltos lankos, 2001. $146 \mathrm{p}$.

[29] LEER, v. Johann. Memelland. Großdeutsche Forderungen. Schriftenreihe zur Frage der nationalen Ansprüche des deutschen Volkes. Heft. 1. München, 1932.

[30] LIŻEWSKA, Iwona. Purda - Die Landschaft lesen. Iš: Purda 1900-2006. Portret wsi. / Gross Purden 1900-2006. Das Portrait eines Dorfes. Sudare M. Kardach, J. Pilecki, E. Traba. Olsztyn: „Borussia“, 2006, p. 77-87.

[31] MAIER, Konrad. Einleitung. Nation und Sprache in Nordosteuropa im 19. Jahrhundert. Bd. 9. Hrsg. K. Maier. Wiesbaden, Veröffentlichungen des Nordost-Institut, 2012, S. 9-12.

[32] MASILIAUSKIENÉ, Daiva. Žodinè istorija ir jos taikymo galimybès buvusių Rytprūsių pokario istorijos tyrimuose. Istorija, 2010, t. 79, Nr. 3, p. 43-53.

[33] MOORHOUSE, Roger. Kariaujantis Berlynas: pakilimas ir nuopuolis Hitlerio sostinejje 19391945. Kaunas: Obuolys, 2013.

[34] POCYTĖ, Silva. Agluonénai. Kaimas istorijos pagaireje (1939-1990). Klaipėda, 1994.

[35] POCYTĖ, Silva. Klaipèdos krašto daugiakalbiškumas ir konfesinio paveldo senosiose kapinèse specifika Lietuvos kontekste. Ǐs: Klaipèdos krašto konfesinis paveldas: tarpdisciplininiai senujju kapiniu tyrimai. Acta historica universitatis Klaipedensis. T. XXV. Sudarè S. Pocytė. Klaipèda: Klaipèdos universiteto 1-kla, 2012, p. 47-53.

[36] POCYTĖ, Silva. Mažlietuviai Vokietijos imperijoje 1871-1914 metais. Vilnius: Vaga, 2002.

[37] POCYTĖ, S. Die memelländische Identität nach dem Zweiten Weltkrieg am Beispiel einer luthterischen Gemeinde. In: Tagungsberichte derhistorischen Kommission für Ost-und Westpreussische Landesforschung. Bd. 26: Memel als Brücke zu den baltischen Ländern. Kulturgeschichte Klaipèda vom Mittelalter bis ins 20. Jahrhundert. Hrsg. B. Jähnig. Osnabrück: fibre Verlag, 2011, S. 119-131. [38] SAFRONOVAS, Vasilijus. Apie repatriaciją ir Lietuvoje vyraujantị požiūrị i Klaipédos krašto senbuvius. Kultūros barai, 2010, Nr. 6, p. 10-14.

[39] SAFRONOVAS, Vasilijus. „Memelenderių“ daryba, arba ideologinis 1939 metų Klaipedos krašto aneksijos parengimas. Iš: Klaipédos krašto aneksija 1939 m.: politiniai, ideologiniai, socialiniai ir kariniai aspektai. Acta Historica universitatis Klaipedensis. T. XXI. Sudarè S. Pocytė. Klaipéda: Klaipedos universiteto l-kla, 2010, p. 32-68. 
[40] SAFRONOVAS, Vasilijus. Modernieji lietuviai ịsitvirtina mieste. Kaip tai vyko Klaipedoje XIX-XX amžių sandūroje. Iš: Klaipėda Europos istorijos kontekstuose: straipsnių rinkinys. Sudare V. Safronovas. Klaipeda: Klaipèdos universiteto 1-kla, 2013, p. 126-151.

[41] SAFRONOVAS, V. Praeitis kaip konflikto šaltinis. Tapatybès ideologiju konkurencija XX amžiaus Klaipédoje. Vilnius: Lietuvos istorijos instituto l-kla, 2011.

[42] SAFRONOVAS, Vasilijus. Trečiojo Reicho jūrų tvirtovè. Iš: Kareivinès, tapusios Klaipédos universitetu. Sudare V. Safronovas. Klaipėda: Klaipėdos universiteto l-kla, 2012, p. 129-141.

[43] SPROGYS, Jurgis. Mažosios Lietuvos enciklopedija. T. IV. Vilnius, 2009, p. 310.

[44] STRAKAUSKAITĖ, Nijolè. Henry Fuchs, der Autor der Niddener Schulchronik. In: Chronik der Schule Nidden. Hrsg. G. Nausèda, V. Gerulaitienè. Vilnius: Petro ofsetas, 2013, p. 17-33.

[45] STRAKAUSKAITE், Nijolè. Kultūros kraštovaizdis prie Kuršių marių. Klaipėda: Klaipèdos universiteto l-kla, 2010. $255 \mathrm{p}$.

[46] Sutuoktuvių liudijimai ir Gimimo ir Krikšto sąrašas nuo 1946 m. - 1954 m. Vanagu evangelikų liuteronu bažnyčios archyvas, b. 7.

[47] TAUBER, Joachim. Der unbekannte Dritte: Die Kleinlitauer im Memelgebiet 1918-1939. In: „Der Fremde im Dorf“: Überlegungen zum Eigenen und zum Fremden in der Geschichte. Hrsg. H.-J. Bömelburg, B. Eschment. Lüneburg: Institut Nordostdeutsches Kulturwerk, 1998, S. 85-104.

[48] TOLEIKIS, Martynas. Ir žodžiai tapo kūnu. Iš: Skaitiniai apie Klaipédos kraštą. Ketvirtoji knyga. Klaipèda: Vejjasparnis, 2008. 254 p.

[49] TRABA, Robert. Tarpdalykinis regiono tyrimas Rytų Prūsijos pavyzdžiu. Iš: Daugiareikšmès tapatybès tarpuerdvèse: Rytu Prūsijos atvejis XIX-XX amžiais. Acta Historica universitatis Klaipedensis. T. XXIII. Sudare V. Safronovas. Klaipeda: Klaipedos universiteto l-kla, 2011, p. 23-30.

[50] VALSONOKAS, Rudolfas. Klaipédos problema. Fotografuotas leidimas. Vilnius: Vaizdas, 1989.

[51] Vanagų ev. liuteronių parapijos Sutuoktuvių liudijimai (prasidedant 1950 m.). Vanagų evangelikų liuteronų bažnyčios archyvas, b. 5.

[52] Vanagų ev. liut. Bažnyčios večerès dalyviai (Komunikantai). Vanagu evangelikų liuteronų bažnyčios archyvas, b. 8.

[53] Vanagų par. (nuo 1968 - K. D. Rogo) Krikštai Konfirmantai. Vanagų evangelikų liuteronų bažnyčios archyvas, b. 3.

[54] Vanagų par. ir kitų parapijų Laidojimai (ir 1999 Šiluteje). Vanagu evangelikų liuteronu bažnyčios archyvas, b. 4.

[55] VAREIKIS, V. Territoire de Memel. Prancūzai Klaipedos kareivinèse. Iš: Kareivinès, tapusios Klaipédos universitetu. Klaipeda: Klaipèdos universiteto l-kla, p. 64-69.

[56] VAREIKIS, Vygantas. 1923 metų Klaipèdos krašto sukilimo kontroversijos. Iš: Klaipédos kraštas 1920-1924 m. archyviniuose dokumentuose. Acta historica universitatis Klaipedensis. T. IX. Sudare S. Pocytė. Klaipèda: Klaipèdos universiteto l-kla, 2003, p. 23-53.

[57] VILEIŠIS, Vincas. Tautiniai santykiai Mažojoje Lietuvoje ligi Didžiojo karo: istorijos ir statistikos šviesoje. Antroji papildyta laida. Vilnius: Versus aureus, 2008.

[58] Wanagų evangelikų parapijos nusidavimai nu jos gruntavojimo ir visų parapijonų sąrašas. Surašytas mete 1949 m. Vanagu evangeliku liuteronu bažnyčios archyvas, b. 6.

[59] Wanagų ev. liut. Parapijiečių Sąrašų Knyga. 1944 - 19 ir Mirusių. 1960. Vanagų evangelikų liuteronu bažnyčios archyvas, b. 1.

[60] Wanagų ev. Liuteronių parapijos Krikšto liudijimai (prasidedant 1955 m. sausio 1 d.). Vanagu evangeliku liuteronu bažnyčios archyvas, b. 2.

[61] WITTENBERG, Erwin. Die Kirchenbücher von Piktupönen. Annaberger Annalen, 2010, Bd. 18, S. 175-178. 
[62] ŽALYS, Vytautas. Lietuvos diplomatijos istorija 1925-1940 metais. Tomas II, pirmoji dalis. Vilnius: Edukologija, 2012. 378 p.

[63] ŽALYS, Vytautas. Lietuvos diplomatijos istorija 1925-1940 metais. Tomas II, antroji dalis. Vilnius: Edukologija, 2012. $374 \mathrm{p}$.

[64] ŽIEMYTĖ, Ivona. Sandèliuke atrasti seni bažnytiniai dokumentai. Vakaru ekspresas, 2010, liepos 21, Nr. 162, p. 2.

[65] ŽOSTAUTAITĖ, Petronèlè. Klaipédos kraštas 1923-1939. Vilnius: Mokslas, 1992.

[66] ŽUKAS, Julius. Istorijos pamokos, arba dar kartą apie tai, kas 1923 m. sausị ívyko Klaipèdos krašte. Iš: Z. Genienė, J. Žukas. Kova dèl Klaipédos. 1923-ieji. Katalogas. Klaipèda, 2003, p. 6-33.

\section{Expressions of cultural and national identity of the residents from the Klaipèda Region Klaipediškiai of the 20th century in epitaphs}

Summary

The history of the Klaipeda Region of the 20th century and its turning-points related to the political changes driven by the world wars has lately received an increasingly growing attention from historians and scientists from other research fields. In addition to the research of political topics of the history of the region, the revelation of the national and cultural expression of the group of residents from the Klaipeda Region, the so called Klaipediškiai, in different periods of history is important as well.

The goal of this article is to reveal the fragments of cultural and national expression of the Klaipediškiai in different periods of the 20th century based on the information that survived in the epitaphs in the historical cemeteries of the Klaipeda Region.

The objectives of the article are the following: to analyse the aspects of cultural and national expression of the Klaipediškiai in the 20th century by revealing the bilingual situation among the residents of the region; to analyse the statistical expression of the Klaipédiškiai after 1945 by comparing the church documents from an EvangelicalLutheran parish and the data of confessional heritage. The chronological limits of the research cover the period until 1960 when, based on the agreement signed between the German Federal Republic and the Soviet Union of 8 April 1958, 8,232 local residents from the Klaipeda Region departed from the Klaipeda Region to Germany in the period of 1956-1969 (the most intensive period: 1958-1960). This turningpoint in the history of the Klaipeda Region manifestly eliminated the existence of original residents of the region in their homeland. Driven to the margins of history, the community was deprived of the opportunity to speak about its past because the public opinion, constrained by ideological chains, either "purified / Lithuanianized" history in its favour or shaped a foreign and unacceptable image of both the entire region and the Klaipediškis in Lithuania by highlighting the understanding of culture and history of the Klaipeda Region based on its exclusively German character. After 1960 the Klaipédiškiai basically assimilated with the remaining part of the society 
and their peculiar character can only be grasped and a certain pulse of identity can be recognised through certain signs of religious environment and church life.

The research results lead to the conclusion that certain insights about the national and cultural expressions of the Klaipediškiai in the 20th century can be drawn by means of a multi-layered base of sources, with epitaphs surviving in the artefacts of confessional heritage playing the major role. The concept of Klaipediškis, having emerged in the public domain of the interwar Klaipeda Region, is defined in the sense of construction of identity relating to both the Lithuanian and German tradition of the knowledge of the past or its interpretation. The analysis of epitaphs leads to the conclusion that the bilingualism of Lithuanian and German languages clearly expressed in the interwar period symbolised an obvious continuity of the linguistic and burial tradition, which had previously dominated in the region.

The fragmentary examples of epitaphs dating back to 1939-1944 testify that the national and cultural expression of local residents was strictly fit into the framework of the national policy pursued by Nazi Germany; therefore, any possibilities of exploitation of the language other than German in the public sphere, or in the culture of cemeteries in our case, were made impossible.

The concept of national expression of the Klaipediškiai in the afterwar period reveals the continuity of the previous cultural / national tradition of local residents from the Klaipeda Region, mostly linked to religious, burial customs.

Irrespective of the strict atheism policy enforced during the Soviet times, the Lutheran Church was an important part of regional history that enabled the preservation of the peculiar identity of local residents. Such a tendency is in a representative manner reflected by epitaphs, where the intertwining German and Lithuanian languages illustrate the continuity of bilingual tradition which had dominated in the region until the outbreak of World War II as well as the national and cultural expression of the Klaipediškiai in the changing political and social environment in the afterwar period. It was a very prominent identification criterion of the Klaipediškiai as their peculiar, different community distinct from those who moved from Lithuania Major in the years after the war.

Key words: Klaipeda Region, confessional heritage, historical cemeteries, Klaipédiškiai 